\title{
Virtue Ethics (Not Too) Simplified
}

\author{
Philip Cafaro \\ Southwest State University
}

\section{Introduction: Virtue Ethics}

There are two basic kinds of ethical judgments. The first has to do with duty and obligation. For example: "Thou shalt not kill, lie or steal." "You should help your brother pay off his debts." These judgments often uphold minimal standards of conduct and (partly for that reason) assert or imply a moral 'ought.' The second kind of judgment focuses on human excellence and the good life. These judgments employ as their most general terms "happiness," "excellence" and perhaps "flourishing" (in addition to "the good life"). For example: "Happiness requires activity and not mere passive consumption." "The good life includes pleasure, friendship, intellectual development and physical health."All ethical judgments are either examples or combinations of these two general types. The first contention of this paper is that we must distinguish them and not try to understand the one as a special case of the other.

Ethical theories may be usefully divided into two main types, deontological or eudaimonist, based on whether they take one or the other of these kinds of judgments as primary. ${ }^{1}$ In the main, ancient ethical theories were eudaimonist in both form and content (in the kinds of judgments and terms they took as primary and in the questions they spent the most time investigating) while most modern ethical theories have been deontological, again in both form and content. The second contention of this paper is that neither

I These terms come from the Greek words for necessity and obligation, and happiness. respectively. David Heyd describes this as a dif ference between deontological and axiological theories (Supererogation: Its status in ethical theory (Cambridge: Cambridge University Press, 1982), 36). Charles Larmore makes a similar distinction, following Sidgwick ("The Right and the Good," Philosophia 20 (1990): 15). 
type of theory should hold prominence over the other, nor should we subsume them under some more encompassing ethical theory.?

The resurgence of "virtue ethics" in the past fifteen years has been tied to a number of disparate projects and positions. 3 In my view, its most important consequence has been to reopen Aristotle's and Augustine's central question - What is the good life and how can we achieve it? - as a major question in philosophical ethics. In reasserting the importance of eudaimonist judgments concerning our flourishing, excellence and happiness, virtue ethics reclaims this neglected half of our ethical lives for intelligent consideration.

For many contemporary ethicists the most important difference between virtue ethics and its Kantian and utilitarian counterparts is that virtue ethics is "agent-centered" rather than "act-centered"; this emphasis has led some to develop virtue ethics primarily as a "character ethics." 4 Whether or not this clarifies or completes

2 Many readers will prefer to divide ethical theories into three basic types --eudaimonist, deontological and utilitarian-- and there are other legitinate typologies. However, twentieth-century moral theory has been preoccupied with the nature and possibility of "the moral ought," and to a lesser extent with a detailed specification of particular duties. It has also neglected questions concerning human excellence and flourishing. In this sense, modern moral theory has been essentially deontological.

3 These have included rejecting the primacy of meta-ethics and the possibility of a moral calculus, and returning to the careful description of concrete moral experience (Martha Nussbaum, The Fragility of Goodness: Luck and Ethics in Greek Tragedy and Philosophy (Cambridge: Cambridge University Press, 1986), 299-306;); developing a communitarian ethics which limits individual rights where these conflict with the common good (Charles Taylor, "Atomism." in Taylor, Philosophy and the Human Sciences (Cambridge: Cambridge University Press, 1985), 187-210); questioning the scope and importance of deontological moral claims (Bernard Williams, Moral Luck (Cambridge: Harvard University Press, 1981), 23-26, 38-39); and turning from a universalist to an historicist moral theorizing (Alasdair Macintyre, After Virtue, 2nd ed. (Notre Dame: University of Notre Dame Press, 1984), 265-72). Good summaries of main trends are Roger Crisp. "Modern Moral Philosophy and the Virtues," in Crisp (ed.), How Should One Live? Essays on the Virmes (Oxford: Oxford University Press, 1996), 1-18; and Gregory Trianosky, "What is Virtue Ethics All About?" American Philosophical Quarterly 27 (1990): 335-344.

4 Among many examples see Larry Blum Moral Perception and Particularity (Cambridge: Cambridge University Press, 1994), 148-149; Nancy Sherman, The Fabric of Character: Aristolle's Theory of Virtue (Oxford: Oxford University Press, 1989), 1-2; David Norton, "Moral Minimalism and the Development of Moral 
deontological ethics, it provides a mistaken view of eudaimonist ethics, which does not focus narrowly on character. Rather, eudaimonist ethics judges the people we are and the lives we lead. In the end, a comprehensive account of the good life must consider our actions, our selves and our personal achievements. 5

The term 'virtue ethics' can also mislead if it is taken to mean an exclusive focus on "the virtues": enduring character traits such as courage and moderation which foster successful achievement and help make a person a good person. Eudaimonist ethics is concerned with such character traits, but only as part of a conception of the good, successful or happy life. This is the more basic consideration and discussions of the virtues make no sense apart from it. 6

Many contemporary ethicists mistakenly specify the virtues as stable dispositions to act according to duty. ${ }^{7}$ This is in line with modern English usage, as the term 'virtue' has taken on a moralistic sense. Eudaimonist ethical theory, however, neither equates the good life and the dutiful life nor defines the virtues narrowly in terms of dispositions to act morally. For we reckon physical, intellectual and psychological qualities as virtues if they typically help people to live well and achieve excellence: to create great works of art or

Character." in Peter French et al. (eds.), Midwest Studies in Philosophy Volume XIII: Ethical Theory: Character and Virtue (Notre Dame: University of Notre Dame Press, 1988), 180: and Guy Axtell, "Recent Work in Virtue Epistemology." American Philosophical Quarterly 34 (1997): 2.

5 As Amartya Sen notes, it is not clear that reason demands that we privilege either character or personal achievement in judging human excellence (The Standard of Living (Cambridge: Cambridge University Press, 1987), 27-28).

6 Julia Annas. The Moraling of Happiness (Oxford: Oxford University Press. 1993) 46.

7 Annas. Morality, 49-52, and the following, all in French et al., Midwest Studies R.B. Brandt, "The Structure of Virtue," 64: Martha Nussbaum. "Non-Relative Virtues," 35: Amelie Rorty. "Virtues and Their Vicissitudes," 137-38. Kant specifies such a moralistic and inward, intentionalist understanding of 'virtue' in a very pure form: "virtue is ... the moral strength of a man's will in fulfilling his duty ." (Kant. The Doctrine of Virtue: Part II of The Metaphysic of Morals (Philadelphia: University of Pennsylvania Press, 1964), 66. For a defense of this Kantian conception of virtue see Onora O'Neill, “Kant's Virtues," in Crisp. pp. 77-97. For a critique see Walter Schaller, "Are Virtues No More Than Dispositions to Obey Moral Rules?" Philosophia 20 (1990): 195-207. 
scholarship, for example, build successful careers or businesses, raise strong and loving families. Such achievements are not typically considered moral (in our restricted modern sense) or matters of duty. Yet they exemplify human goodness and excellence.

The virtue ethics revival points the way towards a better philosophical ethics. Like our ancient predecessors, modern ethical philosophers should attempt to give good advice to those aspiring to live well. But we are more likely to do so if we work to clarify and improve our and their eudaimonist judgments. Virtue ethics will have little use as a new way of dealing with the meta-ethical issues which have bedeviled twentieth-century philosophy or as a new way to speak about moral goodness and other essentially deontological concerns. It sneaks to a different and neglected topic: human excellence and flourishing.8

\section{Deontological and Eudaimonist Judgments}

I began by stating that deontological and eudaimonist judgments should be carefully distinguished. Of course, ethical decisions involve both kinds of judgments, so at some point they must be related, in thought and in action. But these judgments articulate different aspects of our ethical situation, and previous attempts at comprehensive ethical theories have often mischaracterized one type of judgment in an effort to legitimize the other. For these reasons we should first carefully characterize the two kinds of

8 The phrase "enlightened self-interest" best defines the scope of a properly conceived eudaimonist ethics. Perhaps only a minority of writers on "virtue ethics" support a eudaimonist ethics in this sense. Among them see Charles Taylor, "The Diversity of Goods" and Sabina Lovibond, "Realism and Imagination in Ethics," both in Stanley Clarke and Evan Simpson (eds.), Anti-Theory in Ethics and Moral Conservatism (Albany: State University of New York Press, 1989); and Richard Taylor, "Ancient Wisdom and Modern Folly," in French et al., Midwest Studies. However. the majority of the authors in these two representative collections are either critics of eudaimonist ethics or formal virtue ethicists who are in substance deontologists. Such for example is Iris Murdoch, the author of The Sovereignty of Good, who writes that "in the moral life the enemy is the fat relentless ego." (quoted by Lovibond, 270). 
judgments, keeping an open mind as to how far they may be harmonized and a healthy skepticism regarding all comprehensive theories.

Consider an environmental example. Jim owns a 40-acre second growth forest as part of his Wisconsin farm. It is a beautiful forest with a brook running through it which Jim, his father and his own sons have often fished. It has been the scene of family walks, birdwatching expeditions and courtships. It also has been the source for the family's firewood, and of extra income when sections have been cut from time to time. Now Jim has an offer from a regional timber buyer for the trees. The money, of course, would come in handy. He has a decision to make.

What might he believe his duties are in this case? Certainly the duty to provide for his family's well-being; perhaps also to protect the forest; perhaps to keep the farmstead in the family. He might feel as if he "ought" to do all of these things. These "oughts" limit his choices. Such duties mean that he might not get to do what he wants to do - whether he wants to sell the trees or preserve them.

What is in his "enlightened self interest"? Here he will consider what he could buy with the money from the sale, but also the various activities made possible by living next to a beautiful forest. He will consider the happiness of his family as it would be affected by one course of action or another other, and perhaps also the effects on the farmstead itself, both the forest and the adjoining lands (perhaps the forest stands serve to buffer fields from floods and erosion). For these other entities, too, may flourish or decline.9 All these considerations might play a part in his judgments on the advisability of one course of action or another.

Clearly there is one decision to be made here and one family, one farm and one forest (not to say that there are only two choices: perhaps the 40-acres could be harvested in part; harvested in different ways, etc.). Jim's deontological and eudaimonist judgments must both be grounded in the nature of the entities

9 Judgments conceming forest health or preserving biodiversity only refer to Jim's enlightened self-interest on an expansive definition of both 'enlightened' and 'self-interest.' See Ame Naess. Ecology. Community and Lifestyle: Ouline of an Ecosophy (Cambridge: Cambridge University Press, 1989). 8-9. 
concerned and his relationships to them. But the key point is this: he cannot define his duties in terms of his enlightened self-interest or vice versa.

Duties cannot be defined in terms of enlightened self-interest. For our duties are not merely to ourselves but to other beings, and their good sometimes conflicts with our own. Jim may come to the conclusion that the course of action which will lead to his own happiness or self-development is to sell the trees and use the money to go to college or buy a new business. Nevertheless he may have a duty to protect them, based on their intrinsic value. He may, contrarily, decide that his enlightened self-interest dictates protecting the trees and enjoying them in his old accustomed ways. Nevertheless, he may have a duty to sell them in order to support his family. We cannot assume that our self-interest will harmonize with our duties towards others, any more than we can assume they will conflict.

To deny this is to fail to understand the nature of duty. In "Resistance to Civil Government," Thoreau writes that we must consider

those cases to which the rule of expediency does not apply, in which a people, as well as an individual, must do justice, cost what it may. If I have unjustly wrested a plank from a drowning man, I must restore it to him though I drown myself ... he that would save his life, in such a case, shall lose it. 10

The key point here is that duty overrides expediency and selfinterest, by its very definition. This is true whether or not duty ever calls for the absolute sacrifice of one's life. It holds regardless of how often duty and expediency do, in fact, conflict. (It also holds whether or not Thoreau is right in this case, concerning a general

10 Thoreau, Reform Papers (Princeton: Princeton University Press, 1973), 68. "He that would save his life ... shall lose it" refers to Luke 9:24. While the word 'duty' does not occur in the passage quoted, the previous paragraph mentions "this duty ... for honest men to rebel and revolutionize." 
duty to resist a government which denies human rights by protecting slavery and promoting foreign aggression.)

On the other hand, enlightened self-interest cannot be defined by our duties. Even if we exhaustively specified Jim's duties to himself, his family, his neighbors and his forest, we would not have specified his enlightened self-interest. For assuming that he is in the enviable position of having enough money to support his family without selling the trees and leaving open the question of whether he has a duty to protect the trees for their own sakes, the question remains: what would be in his best interest? And if we assume that he decides not to sell or harvest the trees, the question remains: how may he best enjoy the forest?11 Whether the answer involves hunting, fishing and skylarking, or ecological study, or painting and composing poetry, it is clear that none of these activities are duties. Still less can their proper pursuit be explicated in terms of duty. To assume that the best human life is the most dutiful life is to forget that we have freedom as well as constraint in our ethical decisions, legitimate self-interest as well as duties to others, and possibilities for excellence as well as basic injunctions to help and not harm.12

II Similarly, if Jim accepts a duty to protect the forest, the question of how best to protect it remains. This, once again. involves an ef fort to understand the nature and excellence of the forest.

12 Just as we cannot understand duty in terms of enlightened self-interest or vice versa. so we cannot "reduce." define or explain deontological ethical concepts in terms of eudaimonist concepts or vice versa. Many philosophers have made such attempts: for example, Jor ge Garcia holds that "certain virtue concepts are more basic than major deontic concepts" and that "understanding right and wrong action in terms of certain virtue concepts helps us toward understanding and defending traditional Western morality." ("The Primacy of the Virtuous." Philosophia 20 (1990): 69) I see little value in such reductive attempts. Our concepts of duty . law and responsibility, on the one hand. and happiness, excellence and goodness, on the other, are of disparate provenience and often serve dif ferent purposes.

'Duty' may be understood by analogy with man-made laws. We must follow these, or we will be compelled to do so and punished if we do not. From this we move to the idea of a moral law, which holds even in the absence of an obvious law-giver, even in the absence of coercion, even if we are not worried about being found out and punished for breaking it. The moral law holds, regardless of .... The concept of 'goodness,' on the other hand, is used to describe physical entities, both biological organisms and human artifacts. Or ganisms flourish or succeed in 
However, this leaves Jim with the problem of acting on the basis of these two different sorts of judgments, and the problem becomes acute when they push him in opposite directions. For instance, he might come to believe that duty demands that he preserve the trees, while his own best interest involves selling them. Conversely, he might come to believe that he has a duty to his family to sell the trees (let us say his two children need the money in order to go to college), while his own happiness and the health of the land dictate that he preserve them. How might he resolve such dilemmas?

I believe we must leave open the possibility that these will be genuine dilemmas, resolvable in action but not in reason. There may be no best choice here, but rather a number of equally choiceworthy possibilities. Certainly choice often involves picking among mutually exclusive possibilities or making trade-offs between scarce goods. Jim might bow to paternal duty and cut the trees for the sake of his children's education - but with the understanding that his own happiness will suffer. Or he may believe his own happiness and the preservation of the farm dictate preserving the trees, and do so - but recognize that he is failing to perform a duty which his children have a right to demand that he perform.

But it is important to realize that even if this is true in Jim's case, that is not the equivalent of saying "anything goes" or asserting that all choices are equally good. For we must distinguish cases where duty overrides enlightened self-interest, or vice versa, from cases where one or both are overridden by thoughtlessness or mere swinishness. It is not the same case if Jim sells his trees without a

particular environments; artifacts further their makers' purposes more or less well. From this we move to the idea of ethical goodness, the goodness of human beings. We are another kind of thing in the world (albeit a kind of thing in which we are unusually interested, which is unusually variable in its activities and purposes, and which transforms the context in which it understands itself). Ethical goodness is the goodness of human beings in their proper context, properly described, but just what that proper context and description is .... We gain nothing by reconceptualizing duty in terms of goodness or vice versa. Nor can we, by mere wordplay, reconcile those situations where duty and happiness, or duty and the pursuit of excellence, conflict. 
thought as to what they have meant to him and his family, or their role in preventing disastrous floods on his farm. Nor is it the same case if he sells them in order to buy a new Lexus, pay off his gambling debts, or "cover each one of his dollars with another." 13 In none of these cases can we dignify his actions with the name of acting from duty or from enlightened self-interest.

Furthermore, duty and enlightened self-interest often coincide. It may be that the money Jim would get from selling his trees would not compensate him for the pleasure, health benefits, scientific knowledge, poetic inspiration and cherished associations that he would forego if the forest disappeared; and that the intrinsic value of the forest and its many inhabitants places a duty on him not to harm them unnecessarily. Still, we may fail to do right in these cases, as Thoreau put it, "through mere ignorance and mistake," through acting complacently in "the ruts of tradition and conformity," or through "gross feeding": the "betrayal" of our health, ideals and better selves by our "vast abdomens."14 Here both deontological and eudaimonist judgments will condemn us.

\section{Balancing the Two Basic Types of Ethical Judgments}

In the end, it might seem possible to subsume deontological and eudaimonist judgments under a single ethical framework. Deontological moral theories rest on a belief in the intrinsic value or moral considerability of human beings (minority view: some non-human beings, too) an egalitarian sense of "fairness" (the moral law both binds and protects all human beings) and a presumption in favor of rationality and consistency (why treat other people differently than you would yourself want to be treated? why treat one group of human beings differently than another group, when we are essentially the same?).

Eudaimonist theories rest partly on the same basis. They too appeal to rationality and consistency, presupposing that we may rationally decide between possible goals and organize our lives so

13 Thoreau, Walden (Princeton: Princeton University Press, 1971), 294.

14 I bid., 6: 323: 215. 
as to more efficiently pursue them. They too presuppose human dignity and importance (else why enjoin the pursuit of excellence?). But eudaimonist judgments only make sense given the inegalitarian proposition that some lives and some people are better than others. Hence eudaimonist ethical theories are essentially inegalitarian.

This may be the main difference between deontological and eudaimonist ethics. 15 But perhaps these conflicting intuitions concerning human equality can be rationally adjudicated. For (restricting our scrutiny to human beings) we can at least imagine a deontological theory which recognizes differences in the worth of human beings and hence assigns different duties and rights to individuals. In fact, we do not demand the standard duties from those who cannot perform them, while we sometimes do strip individuals of their rights. For example, we do not expect the mentally retarded to vote or blame them if they do not do so, while convicts in the U.S.A. forfeit their right to vote. On the other side of the divide, a eudaimonist ethics might recognize a widespread human excellence or potential for excellence, which would ground our basic, negative duties in a respect for human nature. We acknowledge the superior excellence of a Shakespeare or Newton, but the basic abilities to write and to reason are impressive in themselves, and these are almost universally distributed among us. 16

A consideration of human ends might further bridge the gap between deontological and eudaimonist judgments. Aristotle plausibly centers his eudaimonist ethics on a discussion of the final or chief human end, while Kant formulates one version of the categorical imperative as follows: "Act in such a way that you always treat humanity, whether in your own person or in the person of any other, never simply as a means, but always at the same time as an end." 17 We could reformulate this to include Aristotle's

15 If so, it represents a genuine schizophrenia in our common-sense ethical beliefs. For we both believe and disbelieve in human equality .

16 Alternatively, a eudaimonist theory might minimize our dif ferences. Some philosophers have written that happiness consists in a full belly and a content mind, and that human achievements are transient and of little account. On this view, there is little dif ference in individual excellence and little purpose in attending to that difference.

17 Kant, Groundwork of the Metaphysic of Morals (New York: Harper and Row. 1964), 96. 
injunction to strive for happiness and personal excellence, and to leave open the possibility of treating refractory humans with less respect and some non-human beings with more respect, thus:

Act in such a way that you always treat any being, whether yourself or another, never simply as a means, but always at the same time as an end, to the extent that it deserves such treatment. Further, if this being holds within itself the seeds of a better existence, act whenever possible so as to further its improvement. 18

With this reformulation in mind, consider the following three injunctions:

* Act rationally and consistently!

* Respect human and non-human nature to the extent that they merit it!

* Consider your own ends and the ends of those entities you affect!

Do they suggest a complete ethics which correctly balances our two basic types of ethical judgment? Consider Jim once again, deciding whether to sell his 40 -acre forest.

He feels, let us assume, a duty to protect his trees, a duty to support his family and a duty to himself to develop his higher capabilities. If he considers the nature of the entities affected by his actions, this both grounds his duties (yes, his trees and his sons have intrinsic value, irrespective of his feelings towards them and their usefulness to him) and clarifies them (perhaps duty does not demand that he never cut a tree, but rather that he not cut them all at once; perhaps duty demands that he provide enough money for the family to live on, but not more than this). Such consideration

18 This leaves open the possibility of assigning a diminished moral status to human beings who debase themselves. On a Kantian view this undermines the universality of the categorical imperative and thus undermines its status as categorical. 
of the nature and ends of those beings affected by his decision may dissolve what appeared to be a clash of duties, or a clash between duty and happiness. Perhaps he sells the trees, but insists that the loggers leave a buffer zone around the brook and leave one-third of all large trees standing. This may be sufficient both to protect the forest and to preserve those activities within it which are necessary to his happiness (fishing in the brook, birdwatching along the paths and in the clearings). Or perhaps he does not sell the trees, reasoning that his family does not need the money in order to pursue important or legitimate ends. "Let the kids continue to drive the old Volvo," he might say. "We already have enough money to send them to college, and they will miss the forest as much as I."

Such considerations may solve Jim's problems, but they may not. For he might need to sacrifice his own happiness and the good of the forest to support his children, or sacrifice his children's interests in order to preserve his own happiness and the forest. Conflicts between our various duties, between duty and happiness, and between duty and the pursuit of excellence, are real. Consideration of the three general injunctions above can make such conflicts explicit. But neither this nor any other general framework leads to a definitive balancing of the opposing factors that are typically manifested in the split between our judgments concerning duty and our judgments concerning happiness and personal excellence.

The conflict over egalitarianism has already been mentioned. Look as deeply into human and forest nature as he wishes, into the demands of reason, and into the various ends and excellences of all concerned, these do not specify for Jim a single, rational position which precisely balances the interests of all parties affected by his decisions. For example, he may have to choose whether to spend the money earned from a timber sale on expensive cello lessons for his gifted daughter Kim or on classes at a local community college for his less gifted son Tim. The latter course will help insure that Tim will be able to support himself and live a comfortable life. But the former may allow Kim to develop into a great performer. I do not see a principled way of deciding in this case. 19

19 Of course it is a different story if it is a question of starving Tim in order for Kim to have cello lessons. Perhaps the most perspicuous way to make the point is 
Or assume that the forest can be divided into three equal areas. Area $A$ is the most spectacular of the three, both in terms of harboring several endangered and unique plant communities, in the size and beauty of its trees, and in terms of harvestable timber. Areas $B$ and $C$ are less beautiful, unique and biologically rich, and together contain only as much timber as area A alone. Let's say that Jim's crops have done poorly and he must sell half the timber on his forest. Which areas should he sell? if he saves the more excellent area $A$ then he sacrifices the less excellent, but more extensive and still valuable, areas B and C. It is a toss-up.

Consider next the conflict over ethical egoism. Popular thought tends to equate morality with selflessness and altruism. When modern deontological theories do not do so, they usually advocate equal treatment for all morally considerable individuals. Eudaimonist theories, contrarily, begin from a presumption of justified self-interest: our main concern is and should be with our own happiness and personal excellence. It is not clear that this marks an essential difference between deontological and eudaimonist ethical theories. 20 But be that as it may, it certainly marks an area of contention within moral thought.

Here once again, our more encompassing framework does not fully resolve this conflict. Can Jim legitimately place his own happiness above that of his children in deciding whether to sell his trees? It makes a difference that he owns them, and that his sons will grow up and have the chance to buy their own farms and manage them to suit themselves. Still, we would judge Jim selfish if he gave no weight to the interests of his own family members or his neighbors (perhaps the forest helps protect their lands from flooding). Personal excellence and happiness are best served, often, by minding one's own business; duty, by placing one's own interests on a par with others'. But when these interests conflict, it is difficult

to assume a fixed amount of money to support the two children and to ask whether it must be divided equally. Or. if the closeness of the family bond seems to demand absolute fairness and equality, imagine a school board considering whether to allocate extra funds for gifted students.

20 Julia Annas argues that "the fact that I aim at my own final end makes ancient ethics formally agent-centered or self-centered, but does not make it self-centered in content." (Morality, 223; ibid., 322-25) 
to judge between them, and no comparison of our own needs and desires with those of others will resolve this conflict. Of course, all these interests can be subordinated in an effort to promote common goals and projects. But that they should be so subordinated is a further, and frequently unjustified, assumption.

Consider next the conflict over the scope and force of ethical judgments. Because deontological theories tend, following Kant, to conceptualize ethical duties as universal and categorically binding, they tend also to limit their number and scope. This seems reasonable, because if such duties proliferated too broadly, moral injunctions would both lose some of their unique force, and improperly and unnecessarily crowd our lives with their "thou shalts" and "thou shalt nots." In eudaimonist theories, contrarily, judgments of excellence are both broader in scope and lesser in force. For if "ought implies can" and the deontologist's "ought" implies "should," the eudaimonist's "good" does not necessarily imply either. We often recognize excellence while doubting that it is our duty to achieve such excellence. Jim might be a better father if he took his son fishing or a better naturalist if he went birdwatching at 6 a.m. rather than 9:30 (and if a better father or naturalist, then a better person). Nevertheless it is not his duty to do either. Indeed, we recognize excellences beyond anything we could personally achieve, so that it could never be our duty to achieve them. Jim can recognize the marks of genius in the Audubon prints and Ansel Adams photographs at the art museum in the state capitol, even though he will never duplicate their results in his own efforts.

Arguably, individuals have a general duty of self-improvement and each moment provides us with opportunities to improve. Yet we may justifiably decline to fight a continual war of selfimprovement.21 On one view, to call something a duty is to refer to minimum standards and mark off areas of choice where we must

21 Even Thoreau's Walden, with its repeated injunctions to strive! has its lazier moods: "Sometimes in a summer morning, having taken my accustomed bath. I sat in my sunny doorway from sunrise till noon, rapt in revery . . . A man must find his occasions in himself. . The natural day is very calm, and will hardly reprove his indolence." (111-12) 
act in certain ways. Yet despite many efforts, there is no accepted account of the scope and limits of our duties, understood as ethical minima. Jim has a duty to provide for his children's food and basic education, and he goes beyond the call of duty if he makes time every day to help them with their homework or walk with them in the woods. He is then an excellent father. Yet where duty leaves off and altruism or excellence begins is unclear. Similarly, it is morally arbitrary whether Jim will spend this particular hot summer afternoon fixing fences, keying out rare plants or studying Italian - in short, improving his opportunities - or simply lay down by the brook and catch some zzzs. Nevertheless if Jim spent most of his time snoozing, he would fail in his duty to develop his talents.

An individual's positions on these three issues - egalitarianism, egoism, and ethical striving - are important in specifying his or her personal ethics. Yet they defy precise and non-arbitrary answers, in the sense that all rational beings would or should agree and act similarly if given similar choices. Since radically opposed positions on these issues are typically incorporated into the deontological/ eudaimonist split, we must be careful not to arbitrarily resolve these questions through privileging one or the other kind of theory. 22 And since resolving these issues is part of what we look for in an ethical theory, we should be doubly on our guard. False resolutions are possible, as when moralists write off all self-interest as selfishness, or call non-moral excellence and worldly achievement unimportant, being irrelevant to a basic moral considerability.

\section{Conclusion: Limits to a Narrative Resolution}

The great hope remains that our interests and the interests of others, our duties and our efforts to live well, might be incorporated into a single ethical vision. And so they can be. Jim may tell himself a story about his life and the life of his family on the farm which

22 To reiterate: deontology is typically egalitarian, attacks human egotism, and distinguishes a realm of moral decisions and actions from a realm of non-moral decisions and actions. Eudaimonism is typically inegalitarian, formally and sometimes substantially egoistic, and sees all human life and activity as a matter of better or worse. 
stretches back into the past and on into the future; incorporates basic economic production and poetry, study and skylarking; includes his own interests and the interests of his family, his neighbors and the land. His place within this story specifies both obligations and opportunities. Jim's duties are primarily to entities, human and non-human, which play useful roles in the life of the farm (and utility should not be narrowly defined as economic utility). His sacrifices to duty might be seen as necessary to preserve the life of the farm itself. If this frustrates his own proximate ends, it still furthers the ends of the larger, ongoing concern: preserving the farm's long-term productivity, for example. Jim might sacrifice for the rising generation, but they in their turn will run the farm. This should further his own long-term happiness, providing Jim a place to retire, surrounded by grandchildren and the fields and forests he has known, all protected and cared for into the foreseeable future. 23

Similarly, any happiness or personal excellence made possible by life on the farm is obviously a communal creation, and "living well" might plausibly define the most general goal of the farm as an ongoing entity. This involves basic economic productivity (with everyone pitching in, from the children doing their chores to earthworms turning the soil) and the simple enjoyments of picking huckleberries and swimming in the brook. It can also involve studying nature and singing of its beauty. Thus might the human generations of Jim's family "improve" the landscape and themselves, and tell the farm's stories as they write their own story on the land. (And if the farm produced no scientists or poets, and no spark of science or poetry in its average members, they would hardly be living human lives - anymore than if the farm produced generations of people with no compassion or with no ability to enjoy the pleasures of a picnic by the brook.) Jim may act on the basis of this story and define his roles as father, farmer and fisherman within it. In this way, his deontological and eudaimonist judgments may be deepened, clarified, and perhaps reconciled.

23 Aristotle briefly discusses a sense in which an individual' s happiness may be connected to his descendants' well-being in Ethics, book 1, chapter 10. Similarly our happiness may be connected to projects lasting beyond our death. 
A narrative focus lends some support to ethical objectivism. Given human nature and that Nature we are situated in, we cannot tell just any story about our career within it. Given our particular (sometimes originally free or arbitrary) commitments to certain people, places and social roles, we cannot tell just any story about our personal success or failure. Jim cannot tell a coherent story about his life as a compassionate man who beats his wife and children. He cannot tell an accurate story about his life as a knowledgeable and careful land steward whose topsoil washes down the brook during the spring floods. We may say: "Jim has a duty not to abandon his children or cause excessive topsoil erosion. To do so is morally wrong." We may say: "Jim cannot find happiness or achieve excellence outside of certain general roles such as 'father' or 'knowledgeable resident of a place.' Strong cases can be made for these judgments. 24

Still, even given a respect for facts and an honest attempt to come to grips with them, Jim's life on the farm supports a variety of interpretations. The story that Jim tells himself will incorporate his own limited wit and limitless whim. But even assuming, per impossibile, omniscience and perfect objectivity in the judge, ethical judgments based upon Jim's success or failure in furthering his own ends or the ends of an intergenerational endeavor known as "the farm" will be somewhat indeterminate. Because the components of a good human life - pleasure, health, freedom, friendship, knowledge, a rich experience, personal achievement, etc. - cannot be rank-ordered, specification of Jim's highest good cannot be exact.25 Because the farm is a complex whole, incorporating the many stories of Jim's family members and its non-human residents, specification of its good is difficult (as is

24 Alasdair Macintyre has emphasized the importance of narrative to virtue ethics, correctly insisting that no moral or scientific knowledge, and no persuasive combination of the two. can completely take the place of story-telling in clarifying our ethical judgments. Macintyre clearly hopes that placing individuals' stories within the context of lar ger, more important stories will both clarify the meaning of their lives and actions, and allow for an objectively correct moral evaluation of them (After Virlue. 121-130; Three Rival Versions of Moral Enquiry: Encyclopaedia, Genealogy, and Tradition (Notre Dame: University of Notre Dame Press, 1990), 80; 144).

25 Charles Taylor. "The Diversity of Goods," 223-240. 
telling its story). Finally, because the entities that make up the farm are valuable in their own right, assertions that "the good of the farm" should trump Jim's interests, his son's interests, or the forest's interests, are always open to question.

The facts admit of varied interpretations, yet the particular story told defines the ends of the activities it describes. The limits of narrative objectivity thus illustrate the limited objectivity of any teleological ethical theory. It remains possible to set Jim's life on the farm in still larger frameworks, locating its point and value in something grander: the settlement of the west; the triumph of man over nature; the progress of democracy. Jim himself might explain and justify some of his actions in terms of his role in such important historical movements. Certainly our actions are often tied in to projects which are larger and more important than ourselves: whether raising a family, building a community center or contributing to the progress of knowledge. But to recognize this is to once again admit the enormous complexity and indeterminacy created by the existence of interweaving stories at a variety of levels. For we legitimately refuse to locate the full meaning and value of Jim's life and his little farm in the roles they play in larger historical movements (just as we earlier refused to locate the value of Jim's life solely in terms of furthering the good of "the farm").

For example, increased settlement within the county might dictate condemning Jim's farm and damming the brook to create a reservoir, to insure an adequate water supply. Assuming that 'settlement' means increased population and that we value such settlement above all else, there is nothing wrong with uprooting Jim's family from their farm: further settlement now demands it. But against this, I believe that the story he and his family have written upon the land demands respect and restraint from the community. An individual's particular projects have a value independent of whether they help or hinder the broad social changes going on around them. More generally, there remain genuine dilemmas in balancing public and private interests. Because grand narratives and teleological ethical schemes are more likely to ignore particulars than to resolve conflicts between the general and the particular, they should be treated with skepticism. Jim's greatgrandfather might not have doubted that the imperatives of 
settlement demanded the removal of the Sioux; Jim might think differently as a survey crew moves onto his land and the county sheriff hands him an eviction notice.

Furthermore, even if we grant a preponderant importance to general projects and ends, what they demand of us is somewhat uncertain. We value settlement and honor the pioneers, but what constitutes proper settlement? Do we understand Jim's greatgrandfather's clearing the primeval forest and planting his first crop as the beginning of a new harmony between humanity and nature, or of the taming and control of nature in the service of increased wealth? Let us assume that the past hundred years of white settlement strongly support one or the other of these interpretations: that does not prove that we should continue along this path. Perhaps it was never a good path; perhaps it was good once and is so no longer; perhaps a finer settlement is possible. Whether the rest of the county is being paved over for condominiums or the land is reverting to forest as agriculture becomes less profitable, that is merely what is happening now, not necessarily what is best. Jim must decide whether to buck these trends or accommodate himself to them. It is his life, after all. It is his story.

There is an element of uncertainty here, but also of choice. Jim's family's settlement is an instantiation of Settlement. It is an interpretation of this grand theme with its own meaning, a story with its own excellence or mediocrity. Even if a more consistent and encompassing teleological ethics was convincing, we might willfully reject it, given the value we place on human freedom. In any event, there is no single, encompassing end in which human nature or Nature find their true completion, and which clearly specifies a course of action which we are obliged to follow in reason. Thus even if narrative seems a promising route for reconciling duty and the pursuit of excellence, and our individual and communal projects, the objectivity of any accompanying teleological ethical theory will be limited. Still, we will tell stories about our lives. Our ethical judgments do find a sort of resolution in the stories we tell and the stories we live. 